\title{
AGE, GROWTH AND YIELD PER RECRUIT ANALYSIS OF THE PINTADO Pseudoplatystoma corruscans (AGASSIZ, 1829) IN THE CUIABÁ RIVER BASIN, PANTANAL MATOGROSSENSE, BRAZIL
}

\author{
MATEUS, L. A. F. ${ }^{1}$ and PETRERE JR., M. ${ }^{2}$ \\ ${ }^{1}$ Departamento de Produção Animal, FAMEV/UFMT, CEP 78060-900, Cuiabá, MT, Brazil \\ ${ }^{2}$ Departamento de Ecologia, Instituto de Biociências/UNESP, CEP 13506-900, Rio Claro, SP, Brazil \\ Correspondence to: Lúcia A. F. Mateus, Departamento de Produção Animal, FAMEV/UFMT, \\ CEP 78060-900, Cuiabá, MT, Brazil, e-mail: lmateus@terra.com.br \\ Received October 21, 2002 - Accepted March 25, 2003 - Distributed May 31, 2004
}

(With 5 figures)

\begin{abstract}
The age and growth of the pintado Pseudoplatystoma corruscans were studied during the period from May 1994 to May 1995. The standard length ranged from 52 to $145 \mathrm{~cm}$ and the weight from 1.3 to $41 \mathrm{~kg}$. The biometric relationship between the standard length $\left(\mathrm{L}_{\mathrm{s}}\right)$ and total length $\left(\mathrm{L}_{\text {total }}\right)$ and between the total weight $\left(\mathrm{W}_{\mathrm{t}}\right)$ and the standard length $\left(\mathrm{L}_{\mathrm{s}}\right)$ were obtained for the species, being respectively: $\mathrm{L}_{\text {total }}=3.296+1.069 * \mathrm{~L}_{\mathrm{s}}$ and $\mathrm{W}_{\mathrm{t}}=0.00624 * \mathrm{~L}_{\mathrm{s}}{ }^{3.134}$. The condition factor calculated monthly suggests the spawning season to be between the months of February and March. The age was estimated by counting growth rings present in the spines of the pectoral fins, and 10 age classes were detected. The mean distance of the last ring until the border of the spine suggests that the period of least growth is between July and September (dry period). Von Bertalaffy's equation describing the growth of the pintado is: $\mathrm{L}_{\mathrm{t}}=183 *[1-\exp -0.085 *(\mathrm{t}+3.274)]$. Total mortality was $\mathrm{Z}=0.24$ year $^{-1}$ and natural mortality $\mathrm{M}=0.20$ year $^{-1}$. As the present level of exploitation, $\mathrm{F}=\mathrm{Z}-\mathrm{M}=0.04 \mathrm{year}^{-1}$, we conclude that the pintado stock was still underexploited in the Pantanal in the sampled period.
\end{abstract}

Key words: Pantanal, Pseudoplatystoma, age, growth, mortality.

\section{RESUMO}

Idade, crescimento e rendimento por recruta do pintado Pseudoplatystoma corruscans (Agassiz, 1829) na bacia do rio Cuiabá, Pantanal de Mato Grosso, Brasil

A idade e o crescimento do pintado Pseudoplatystoma corruscans foram estudados durante o período de maio de 1994 a maio de 1995. O comprimento-padrão variou de 52 a $145 \mathrm{~cm}$ e o peso total, de 1,3 a $41 \mathrm{~kg}$. As relações biométricas entre comprimento-padrão $\left(\mathrm{L}_{\mathrm{s}}\right)$ e comprimento total $\left(\mathrm{L}_{\text {total }}\right)$ e entre peso total $\left(\mathrm{W}_{\mathrm{t}}\right)$ e comprimento-padrão $\left(\mathrm{L}_{\mathrm{s}}\right)$ foram obtidas, sendo, respectivamente: $\mathrm{L}_{\text {total }}=3,296+1,069 * \mathrm{~L}_{\mathrm{s}} \mathrm{e}$ $\mathrm{W}_{\mathrm{t}}=0,00624 * \mathrm{~L}_{\mathrm{s}}^{3,134}$. O fator de condição, calculado mensalmente, sugere que a desova ocorreu entre os meses de fevereiro e março. A idade foi estimada pela contagem de anéis de crescimento presentes nos raios modificados (esporão) das nadadeiras peitorais, detectando 10 classes etárias. A distância média do último anel até a borda do esporão sugere que o período de menor crescimento ocorreu entre julho e setembro (seca). A equação de von Bertalaffy que descreve o crescimento do pintado é: $L_{t}=183$ * $[1-\exp -0,085 *(t+3,274)]$. A mortalidade total obtida foi $Z=0,24 \mathrm{ano}^{-1} \mathrm{e}$ a mortalidade natural $\mathrm{M}=0,20 \mathrm{ano}^{-1}$. Com o presente nível de explotação, $\mathrm{F}=\mathrm{Z}-\mathrm{M}=0,04 \mathrm{ano}^{-1}$, conclui-se que o estoque do pintado ainda não estava sobrexplotado na bacia do rio Cuiabá, Pantanal Matogrossense, na época em que foi realizado o estudo.

Palavras-chave: Pantanal, Pseudoplatystoma, idade, crescimento, mortalidade. 


\section{INTRODUCTION}

Pseudoplatystoma are Siluriformes of the family Pimelodidae, which accomplish periodic migratory movements for reproduction (LoweMcConnel, 1975). To this genera belong catfish species of high economic value in their occurrence areas. Therefore, they are an object of interest in fishery biology. Examples of studies of the genera are Bonetto et al. (1965), with the Pseudoplatystoma corruscans and the Pseudoplatystoma fasciatum, and Cordiviola (1966) with P. corruscans in the middle Paraná. Reid (1983) and Marques (1993) investigated, respectively, the biology of $P$. fasciatum and P. tigrinum in the basin of the river Apure River, Venezuela, and of $P$. corruscans in the basin of the River Paraná. Gil \& Martinez (1995) examined biological and fishery aspects of $P$. fasciatum and P. corruscans in the high Meta River, Colombia. Ruffino \& Isaac (1999) described the population dynamics of P. tigrinum in the middle Amazon; Loubens \& Panfili (2000) studied the biology of $P$. fasciatum and P. tigrinum in the basin of the Mamoré River, Bolivia and, recently, García et al. (2001) studied reproductive aspects of $P$. fasciatum and P. tigrinum in Peruvian Amazonia.

In the Pantanal Matogrossense, this genera is represented by the pintado $P$. corruscans and cachara P. fasciatum. According to Ferraz de Lima (1987), besides being vulnerable to fishery activity during reproduction, they are also threatened by environmental alterations due to the multiple use of fluvial systems. Due to the high commercial value of the pintado, immature individuals $(<80 \mathrm{~cm})$ are landed (Ferraz de Lima \& Chabalin, 1984).

The aim of this work was to estimate the age of $P$. corruscans through growth checks of the spine and to estimate the von Bertalanffy growth parameters in order to assess the present exploitation level of the stock in the Cuiabá River basin.

\section{MATERIAL AND METHODS}

The Paraguay River basin, of which the Cuiabá River is an important affluent, embraces approximately $496,000 \mathrm{~km}^{2}$, with an extensive floodplain of 138,000 $\mathrm{km}^{2}$, known as the Pantanal Matogrossense (Adámoli, 1982). The Pantanal presents a tropical climate, with an annual average temperature of $25.1^{\circ} \mathrm{C}$. December is the hottest month, and July the coldest.
The annual hydrological regime can be defined, according to Silva (1990), into four periods: high water (HW); January, February, and March, the rainy period leading to inundation of the floodplain; descending water (DW), April, May, and June, the period of descending water, when it returns to the riverbed; dry, July, August, and September - period in which the river flows within the channel; rain water (RW), October, November, and December, beginning of the rains, period in which the level of the river begins to rise.

The total and standard length $\left(\mathrm{L}_{\text {total }}\right.$ and $\mathrm{L}_{\mathrm{s}}$, respectively) of 2222 Pseudoplatysoma corruscans were measured from specimens landed at the fish market in the City of Cuiabá, Mato Grosso, between May 1994 and May 1995. The individual total weight of 985 fish was taken. Identification of sex of measured fish was impossible as they were going to be sold. The $\mathrm{L}_{\text {total }} \times \mathrm{L}_{\mathrm{s}}$ relationship was calculated by the linear regression $L_{\text {total }}=c+d . L_{s}$. The length and weight relationship was derived according to $\mathrm{W}_{\mathrm{t}}=\mathrm{a} \cdot \mathrm{L}_{\mathrm{s}}^{\mathrm{b}}$ where $\mathrm{Wt}$ is the total weight $(\mathrm{g})$ and $\mathrm{L}_{\mathrm{s}}$, the standard length $(\mathrm{cm})$. The allometric condition factor (ACF) was calculated monthly as follows: $\mathrm{ACF}=\mathrm{W}_{\mathrm{t}} / \mathrm{L}_{\mathrm{s}}^{\mathrm{b}}$ (Ricker, 1975).

The age and the average length of each age group were estimated from examining the hard structures. Sections of pectoral fin spines of 221 fish ( 5 sections per fish) were used to estimate the age, following the procedure of Barthem (1990).

To test the validity of the rings as age discriminators, data for each month were pooled to assess whether the annulus was close to the edge of the spine. The distance between the last ring and the border was measured and its mean was calculated for each month and for each hydrological period (Rossi-Wongtschowski et al., 1982; Braga \& Goitein, 1985). This procedure was performed for 4 -yearold individuals, which was the most frequent age class, and for all ages combined.

The von Bertalanffy growth curve in length for the pintado was estimated by: $\mathrm{L}_{\mathrm{t}}=\mathrm{L} \infty(1-\exp$ $\left(-\mathrm{k}\left(\mathrm{t}-\mathrm{t}_{\mathrm{o}}\right)\right)$ where: $\mathrm{L}_{\mathrm{t}}(\mathrm{cm})-$ length at age $\mathrm{t} ; \mathrm{L} \infty$ $(\mathrm{cm})$ - mean asymptotic length; $\mathrm{k}\left(\right.$ year $\left.^{-1}\right)$ - growth coefficient; and to (year) - the nominal age at which the length is zero (Beverton \& Holt, 1957). These parameters were estimated through non-linear regression between the average standard length versus age. The von Bertalanffy growth curve in weight was estimated by: $\mathrm{W}_{\mathrm{t}}=\mathrm{W}_{\infty} \cdot(1-\exp (-\mathrm{k}(\mathrm{t}-\mathrm{to})))^{\mathrm{b}}$, where 
$\mathrm{W}_{\mathrm{t}}$ is the total weight at age $\mathrm{t}$, and $\mathrm{W}_{\infty}$ is the maximum weight the fish would reach if they lived indefinitely (Gulland, 1969).

Total mortality $(\mathrm{Z})$ was calculated by: $Z=(\mathrm{n} . \mathrm{k} /$ $(\mathrm{n}+1))\left(\ln \left\{\left(\mathrm{L} \infty-\mathrm{L}_{\mathrm{c}}\right) /(\mathrm{L} \infty-\mathrm{e}\}\right)^{-1}\right.$ and the $\mathrm{Z} / \mathrm{k}$ variance by: $\operatorname{var}(\mathrm{Z} / \mathrm{k})=\left\{\left[\mathrm{n} /(\mathrm{n}+1)^{2}\right]\right\} .\{\mathrm{n}[\ln ((\mathrm{L} \infty-$ $\left.\left.\left.\mathrm{L}_{\mathrm{c}} /(\mathrm{L} \infty-)\right)\right]\right\}^{-2}$ (Ssentongo \& Larkin, 1973) where: $\mathrm{n}$ is the number of measured fishes; $\mathrm{k}$, the growth coefficient; L $\infty$, asymptotic length $(\mathrm{cm}) ; \mathrm{L}_{\mathrm{c}}$, the size of the smaller fish; and e, the average length in the catch.

Natural mortality $(\mathrm{M})$ was calculated according to the Pauly (1980) relationship: $\ln \mathrm{M}=-0.0152-$ $0.279 \ln \mathrm{L} \infty+0.6543 \ln \mathrm{k}+0.4634 \ln \overline{\mathrm{T}}$, where $\overline{\mathrm{T}}$ is the annual average water temperature in ${ }^{\circ} \mathrm{C}$; as water surface temperature is close to air temperature, the latter was utilized in the equation above in order to estimate $\mathrm{M}$.

Relative yield per recruit (Y/R') was performed according to the procedures of Beverton \& Holt (1966): Y/R' $=\mathrm{EU}^{\mathrm{M} / \mathrm{k}}\left[1-(3 \mathrm{U} / 1+\mathrm{m})+\left(3 \mathrm{U}^{2} / 1+\right.\right.$ $\left.2 \mathrm{~m})-\left(\mathrm{U}^{3} / 1+3 \mathrm{~m}\right)\right]$, where $\mathrm{m}=(1-\mathrm{E}) /(\mathrm{M} / \mathrm{k})=$ $\mathrm{k} / \mathrm{Z}, \mathrm{U}=1-(\mathrm{Lc} / \mathrm{L} \infty)$, and $\mathrm{E}=\mathrm{F} / \mathrm{Z}$ (rate of exploitation).

\section{RESULTS}

The range of the standard length between $52 \mathrm{~cm}$ to $145 \mathrm{~cm}$, with median length of $90 \mathrm{~cm}$, and the total weight of the individual fish was between 1.3 $\mathrm{kg}$ to $41 \mathrm{~kg}$. Fig. 1 shows the standard length frequency distribution.

The relationship between the total length and standard length is described by: $\mathrm{L}_{\text {total }}=3.296+1.069$ $\mathrm{L}_{\mathrm{s}} ; \mathrm{r}=0.996 ; \mathrm{n}=2222$.

The regression between total weight $(\mathrm{kg})$ and the standard length $(\mathrm{cm})$ was: $\mathrm{W}_{\mathrm{t}}=0.00624 \mathrm{~L}_{\mathrm{s}}^{3.134}$; $\mathrm{r}=0.983 ; \mathrm{n}=985 ; \mathrm{se}=0.121$, originally calculated in logarithmic scale.

The monthly average allometric condition factor showed that the largest values occurred in March 1995, followed by an abrupt fall in April 1995 (Fig. 2).

The validation of checks periodicity is observed in Fig. 3, where we can see the monthly mean of the distance between the last ring and the border of the spine for all age together and for the four age class checks. In this figure, July, August, and September present the smallest distances, demonstrating that the rings were formed in the dry season. Thus, ring formation was found to be an annual event and each group with the same number of rings was considered an age class or cohort.

The readings of translucent marks in the pectoral fin sections indicated 10 groups of rings. The individuals with 10 or more rings were classified in the same class $(\mathrm{X}+)$, because of the proximity between rings. As is usual in older specimens, counting was impossible beyond the tenth mark because subsequent ones were imprecise.

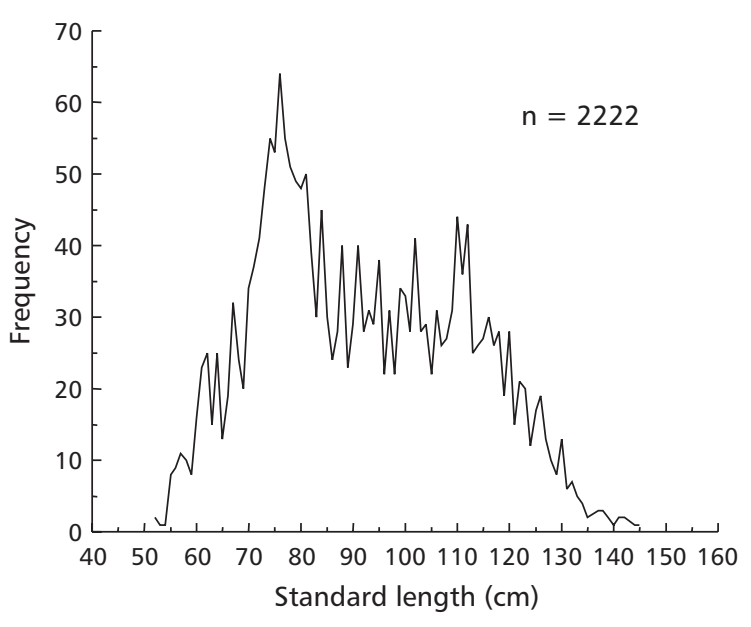

Fig. 1 - Standard length frequency distribution of Pseudoplatystoma corruscans, measured from May 94 to May 95 in the fish landed in Cuiabá Fish Market. 


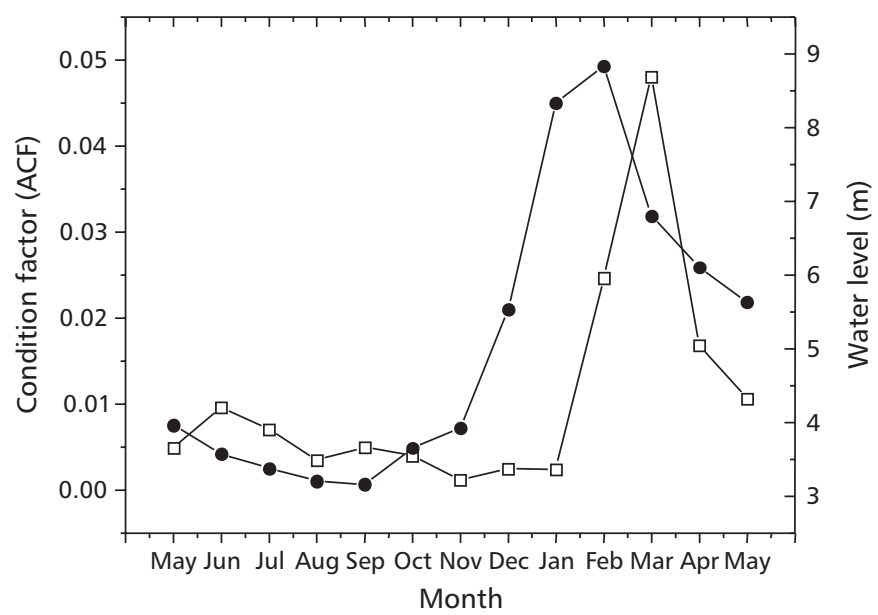

Fig. 2 - Monthly allometric condition factor (- $\square-$ ) calculated for Pseudoplatystoma corruscans and monthly average water level (m) in the River Cuiabá (- - ) recorded in the town of Santo Antônio de Leveger (MT) from May 1994 to May 1995.

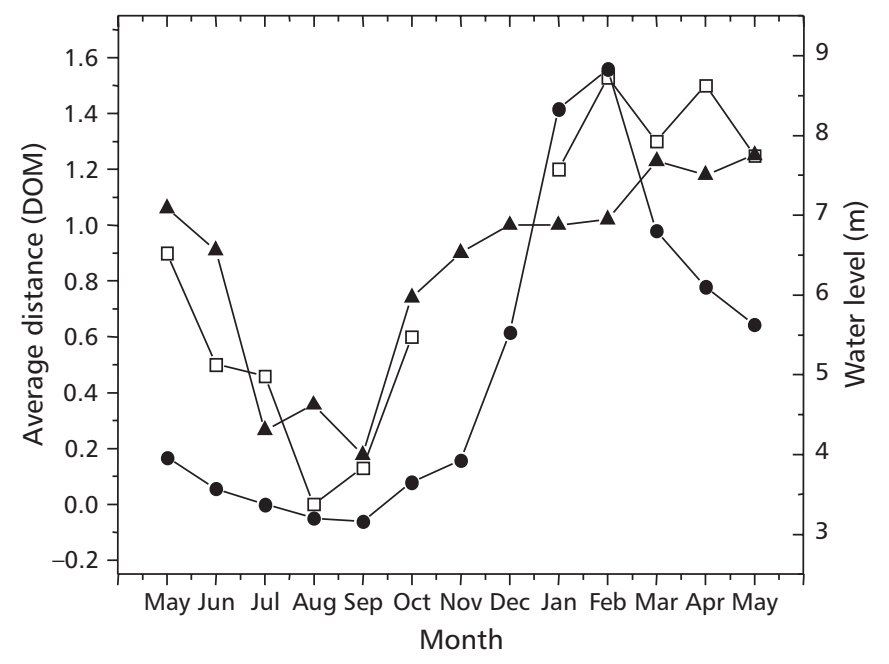

Fig. 3 - Monthly average distance (DOM - Divisions of Ocular Micrometer) between the last ring and the border of the spine for all ages combined (- - ) and for 4-years-old individuals ( $-\square-$ ) for Pseudoplatystoma corruscans (note the lack of data for November and December) and monthly average water level $(\mathrm{m})$ in the River Cuiabá (- - -) recorded in Santo Antônio de Leveger (MT) from May 1994 to May 1995.

As was already pointed out, the final age was only taken into account for the slides in which at least 2 of the 3 readings coincided. In this way, 210 fish had their ages confirmed. Table 1 summarizes these findings and presents the size variability within age classes. Table 2 presents the frequency distribution of the standard length $\left(\mathrm{L}_{\mathrm{s}}, \mathrm{cm}\right)$ classes by age.
Experienced fishermen at Cuiabá Fish Market informed us that the maximum total length of pintado years ago was about $200 \mathrm{~cm}\left(\mathrm{~L}_{\mathrm{s}}=183 \mathrm{~cm}\right)$. Forcing this value in the von Bertalanffy growth curve, we estimated $\mathrm{k}=0.085$ year $^{-1}$ (ASE $=$ asymptotic standard error $=0.003$ year $\left.^{-1}\right)$ and $t_{0}=-3.274$ years $(\mathrm{ASE}=$ 0.261 years), $r^{2}=0.992, n=9$. This result is robust 
as it was found independent of any initial value of $\mathrm{k}$ and $t_{0}$. The equations which describe the growth in length $(\mathrm{cm})$ and weight $(\mathrm{kg})$ for $P$. corruscans are respectively: $\mathrm{L}_{\mathrm{t}}=183[1-\exp -0.085(\mathrm{t}+3.274)]$ and $\mathrm{W}_{\mathrm{t}}=77[1-\exp -0.085(\mathrm{t}+3.274)]^{3.134}$. Fig. 4 shows the length on age growth curve.

The mean standard length of first capture was adopted as $52 \mathrm{~cm}$, and the mean length in the catch, $\overline{\mathrm{e}}=91 \mathrm{~cm}$. Using these and adopting $\mathrm{k}=0.085 \mathrm{year}^{-1}$ gives $Z=0.24$ year $^{-1}$ and $\operatorname{var}(Z / k)=0.85^{*} 10^{-6}$. Considering $\mathrm{T}=25.1^{\circ} \mathrm{C}$, Pauly's formula gives $\mathrm{M}=$ 0.20 year $^{-1}$. Fig. 5 shows the yield per recruit plot where $\mathrm{F}_{\max }=0.20$ year $^{-1}$. As the present level of exploitation is $\mathrm{F}=\mathrm{Z}-\mathrm{M}=0.04$ year $^{-1}$, we can conclude that pintado stock was still underexploited in the Pantanal in the sampled period.

TABLE 1

Minimum, maximum, and mean standard length, the standard deviation and the examined number of individuals for each age class (1 year interval) of the standard length $\left(\mathrm{L}_{\mathrm{s}}, \mathrm{cm}\right)$ of Pseudoplatystoma corruscans. Readings from the pectoral fin spine.

\begin{tabular}{|c|c|c|c|c|c}
\hline Age class & $\mathbf{L}_{\mathbf{s}} \mathbf{m i n}$. & $\mathbf{L}_{\mathbf{s}} \mathbf{m a x}$ & $\mathbf{L}_{\mathbf{s}} \mathbf{m e d}$ & $\mathbf{S D}$ & $\mathbf{N}$ \\
\hline I & 55.0 & 66.5 & 58.75 & 5.23 & 4 \\
\hline II & 59.0 & 73.0 & 65.26 & 4.04 & 27 \\
\hline III & 70.0 & 84.0 & 75.78 & 3.54 & 29 \\
\hline IV & 74.0 & 89.0 & 83.16 & 3.63 & 25 \\
\hline V & 83.0 & 97.0 & 90.36 & 4.32 & 25 \\
\hline VI & 90.0 & 108.0 & 98.06 & 4.42 & 24 \\
\hline VII & 100.0 & 114.0 & 107.58 & 4.27 & 19 \\
\hline VIII & 105.0 & 123.0 & 114.60 & 4.65 & 24 \\
\hline IX & 115.0 & 127.0 & 121.25 & 3.22 & 12 \\
\hline X+ & 120.0 & 145.0 & 131.05 & 6.45 & 21 \\
\hline
\end{tabular}

TABLE 2

Standard length $\left(\mathrm{L}_{\mathrm{s}}, \mathrm{cm}\right)$ frequency distribution for each age of Pseudoplatystoma corruscans, from readings in the pectoral fin spine.

\begin{tabular}{|c|c|c|c|c|c|c|c|c|c|c|c|}
\hline \multirow[b]{2}{*}{$\mathbf{L}_{\mathrm{s}}(\mathbf{c m})$} & \multicolumn{11}{|c|}{ Age } \\
\hline & I & II & III & IV & $\mathbf{V}$ & VI & VII & VIII & IX & $\mathbf{X}+$ & $\mathbf{N}$ \\
\hline $50-60$ & 3 & 3 & - & - & - & - & - & - & - & - & 6 \\
\hline $61-70$ & 1 & 20 & 3 & - & - & - & - & - & - & - & 24 \\
\hline $71-80$ & - & 4 & 25 & 6 & - & - & - & - & - & - & 35 \\
\hline $81-90$ & - & - & 1 & 19 & 12 & 2 & - & - & - & - & 34 \\
\hline $91-100$ & - & - & - & - & 13 & 16 & 1 & - & - & - & 30 \\
\hline $101-110$ & - & - & - & - & - & 6 & 13 & 5 & - & - & 24 \\
\hline $111-120$ & - & - & - & - & - & - & 5 & 16 & 5 & 1 & 27 \\
\hline $121-130$ & - & - & - & - & - & - & - & 3 & 7 & 10 & 20 \\
\hline $131-140$ & - & - & - & - & - & - & - & - & - & 8 & 8 \\
\hline $141-150$ & - & - & - & - & - & - & - & - & - & 2 & 2 \\
\hline & & & & & & & & & & & $=21$ \\
\hline
\end{tabular}




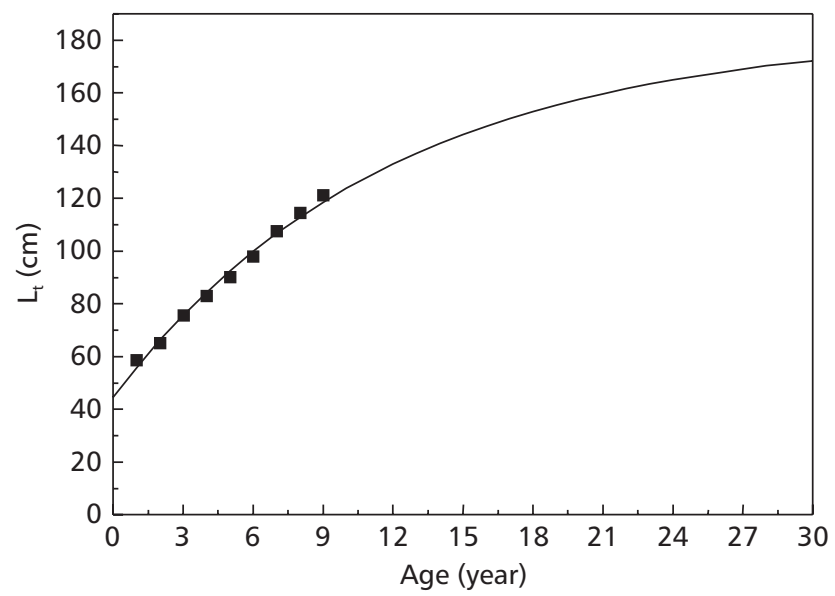

Fig. 4 - Length growth curve estimated (line) $\mathrm{L}_{\mathrm{t}}=183 *[1-\exp -0.085 *(\mathrm{t}+3.274)]$ and observed mean length at age ( $\left.\mathbf{\square}\right)$ of Pseudoplatystoma corruscans in the Cuiabá River basin.

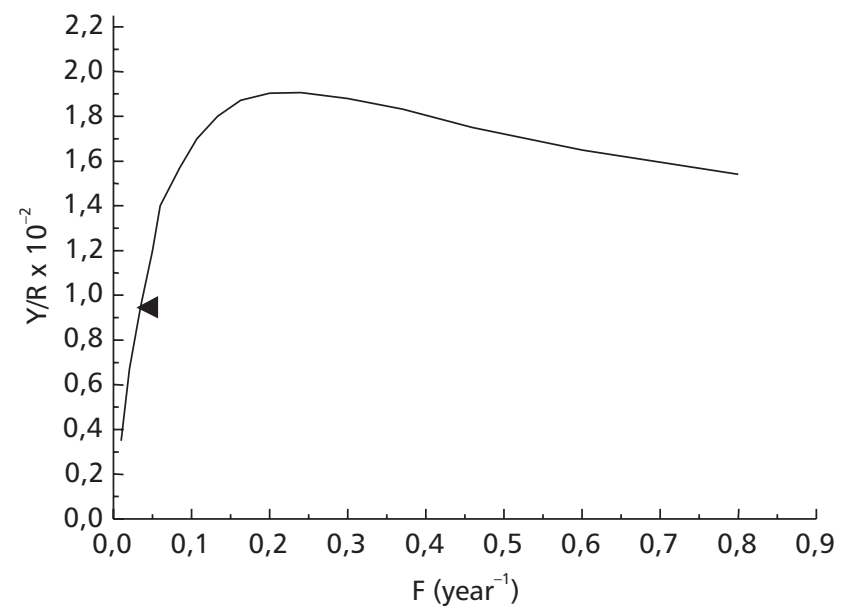

Fig. 5 - Relative yield per recruit (Y/R') versus fishing mortality (F) for Pseudoplatystoma corruscans in the Cuiabá River basin, (4) present value of $\mathrm{F}$.

\section{DISCUSSION}

Pseudoplatystoma corruscans is a species, which can reach a large size. As we said, fishermen with long experience in the Pantanal report that it can attain $200 \mathrm{~cm}$ in total length (and $183 \mathrm{~cm}$ in standard length, calculated by the equation: $\mathrm{Ls}=$ $-2.392+0.928 \mathrm{~L}_{\text {total }}$ ). Godinho et al. (1993) reported individual fish of $182 \mathrm{~cm}\left(\mathrm{~L}_{\text {total }}\right)$ in the São Francisco River. Probably this is one of the representatives of the genera that reach larger lengths, considering that $P$. fasciatum and P. tigrinum, do not surpass $130 \mathrm{~cm}$ in total length (Reid, 1983). In the present study, the largest pintado measured $\mathrm{L}_{\text {total }}=152 \mathrm{~cm}$.
The smallest individual measured in this work was $59 \mathrm{~cm}$ in total length $\left(\mathrm{L}_{\mathrm{s}}=52 \mathrm{~cm}\right)$, albeit the minimum allowable marketable size was $\mathrm{L}_{\text {total }}=80$ $\mathrm{cm}$ (recently that was changed to $85 \mathrm{~cm}$ by fishery regulation). Therefore, fish below this size are illegally marketed.

Smaller samples were measured in November, December, and January because during this period, fishing is limited due to its being a closed season (which is not entirely respected) in order to protect the spawning fish.

The condition factor expresses the physiological state of the fish, which results from the interaction between biotic and abiotic factors, indicating the recent 
nutrition conditions and varying according to the cycle of sexual maturity which associated with other evidence, roughly indicates when fish reproduction begins (Vazzoler, 1996). For pintado, a high value of the condition factor in March may indicate the period of pre-spawning, as is also evidenced by the fact that this high value is preceded by a gradual increase of ACF in January and February, which points to fat accumulation and investment in gonad maturation. In April, the ACF suffers a sudden fall, probably caused by the energy demand during spawning. Therefore, the condition factor corroborates spawning time in the high water season, as pointed out by Ferraz de Lima (1987). The same was observed by Marques (1993), who verified a direct relationship between the reproductive peak of $P$. corruscans and the high water season of the upper Paraná River, and also by Godinho et al. (1993) for the São Francisco River.

The period of growth activation as indicated by a slight ACF increase was in May and June when the waters recede. In this period, the shoals begin to leave flooded areas, and head back to the riverbed, in what is a period of great for opportunity fish-eating animals. In July, the ACF decreases, remaining low till December, indicating growth deceleration. Similar results were found by Reina et al. (1995) who verified formation of translucent marks in the jaú Paulicea luetkeni, during low water in the high Meta River, Colombia.

The pectoral fin spines proved reliable structures for ageing the pintado since they generally presented, distinct and well-marked rings. Besides, Table 2 shows the consistant relationship between the average standard length and the number of rings, indicating clearly that large individuals present more rings.

The smallest mean values observed in the distance between the last ring and the border of the spine in July, August, and September (dry period) suggest that this is when the translucent marks form, accompanied by growth deceleration which is also indicated by a low ACF. Therefore, the annual age ring probably forms in this period.

Resende et al. (1986) also verified ring formation in the dry season for pintado caught in the Miranda River basin (Southern Pantanal). Reid (1983), in the Apure River basin, Venezuela, and Loubens \& Panfili (2000), in the Mamoré River basin, reported similar observations in the case of $P$. fasciatum and $P$. tigrinum

$P$. corruscans presents a comparatively low growth rate $\left(\mathrm{k}=0.085\right.$ year $\left.^{-1}\right)$. Reid (1983) observed the same thing for P. tigrinum $\left(\mathrm{k}=0.088\right.$ year $\left.^{-1}\right)$ and $P$. fasciatum $\left(\mathrm{k}=0.097\right.$ year $\left.^{-1}\right)$ in the Apure River basin in Venezuela.

As is common in tropical multispecies inland fisheries, there is no easier and readier way to estimate natural mortality than by using Pauly's formula and, as the estimates of $M$ and $Z$ are coherent $(\mathrm{M}<\mathrm{Z}$, as it should be in an exploited stock), we have adopted it since informed advice is urgently required in heuristically-managed fishery.

As for the classical criticisms of the Beverton \& Holt (1957) model, are they viewed by us as a case in point of excessive zeal. Furthermore, this model a currently is the only one we can use in a region for which data are scarce. Vaz (2001) and Mateus \& Estupiñán (2002) used this model in order to assess, respectively, the pacu Piaractus mesopotamicus and piraputanga Brycon microlepis fish stocks in the Cuiabá River basin. The first author concluded that pacu is overfished and the second found that piraputanga is not overfished, yet.

Experienced fishermen say that the average size of pintado is consistently decreasing, however, the mean size related by Ferraz de Lima \& Chabalin (1984) between 1980 to 1983 was not much larger than that estimated in this work. Moreover our findings suggest that the survival rate is still high ( $\mathrm{S}=\exp -Z=79 \%$ ) and growth overfishing has not been reached by the pintado fish stock in the Cuiabá River basin. Catella (2001) found the same result for the Paraguai River basin, having assessed effort and catch between 1994 and 1999 in the state of Mato Grosso do Sul. However, due to the great commercial value of the species regular attention must be paind to the stock in order to avoid growth (and recruitment) overfishing. Environmental care is also needed, due to deforestation and water pollution.

Acknowledgments - We would like to thank UFMT, Cuiabá, and UNESP, Rio Claro, for its financial support. Profa. Dra. Nídia Fabré (UFAM), Prof. Dr. Francisco of Souza Braga (UNESP), and Prof. Dr. Nicolau Priante Filho (UFMT) are thanked for criticisms.

\section{REFERENCES}

ADÁMOLI, J., 1982, O Pantanal e suas relações fitogeográficas com os cerrados. In: Anais do 32. Congresso Nacional de Botânica, pp. 109-119

BARTHEM, R. B., 1990, Ecologia e pesca da piramutaba (Brachyplatystoma vaillanti). PhD Thesis, Instituto de Biociências, UNICAMP Campinas, SP, 268p. 
BEVERTON, R. J. H. \& HOLT, S. J., 1957, On the dynamics of exploited fish populations. Fish Invest. Minist. Agric. Fish. Food, v. 19, 533p.

BEVERTON, R. J. H. \& HOLT, S. J., 1966, Manual of methods for fish stock assessment. Part 2. Tables of yield functions. FAO Fish. Tech. Pap. 38, 67p.

BONETTO, A. A., PIGNALBERI, C. \& CORDIVIOLA, E., 1965 , Notas preliminares par un estudio biológico e pesqueiro del "surubim" (Pseudoplatystoma coruscans y P. fasciatum) en el Paraná medio (Pisces, Pimelodidae). Anais do II Congresso Latino Americano de Zoologia, São Paulo, pp. 125-129.

BRAGA, F. M. S. \& GOITEIN, R., 1985, Estudo morfológico da Sagitta da cabrinha (Prionotus punctatus, Triglidae), da região da Ilha Anchieta (Lat. $23^{\circ} 33^{\prime} \mathrm{S}$ - Long. $45^{\circ} 05^{\prime} \mathrm{W}$ ), Ubatuba, litoral norte do Estado de São Paulo, Brasil. Naturalia, 10: 65-74

CATELlA, A. C., 2001, A pesca no Pantanal de Mato Grosso do Sul, Brasil: descrição, nivel de exploraçao e manejo (1994 - 1999). PhD Thesis, INPA, Manaus, AM.

CORDIVIOLA, E., 1966, Nuevos aportes al conocimiento de la biología pesquera del "surubi" (Pseudoplatystoma coruscans) en el Paraná medio (Pisces, Siluriformes). Physis, 36: $237-244$

FERRAZ DE LIMA, J. A., 1981, A pesca no Pantanal de Mato Grosso (rio Cuiabá: aspectos da produção pesqueira). Anais do II Congresso Brasileiro de Engenharia de Pesca, Recife, PE, pp. 517-529.

FERRAZ DE LIMA, J. A., 1987, A tecnologia de pesca no Centro-Oeste do Brasil (Bacia do Alto Paraguai: Pantanal de Mato Grosso). V Congresso Brasileiro de Engenharia de Pesca, Fortaleza, CE, pp. 305-323.

FERRAZ DE LIMA, J. A. \& CHABALIN, E., 1984, O Mercado dos Peixes. Prefeitura Municipal de Cuiabá, Cuiabá, 96p.

GARCÍA, A., MONTREUIL, V. \& RODRÍGUEZ, R., 2001, Talla de la primeira maturación y época de desova de la "doncella", Pseudoplatystoma fasciatum (Linnaeus), y el "tigre zúngaro", Pseudoplatystoma tigrinum (Valenciennes), en la Amazonía Peruana. Bul. Mus. Para. Emílio Goeldi, ser. Zool., 17: 3-13.

GULLAND, J. A., 1969, Manual of methods for fish stock assessment. Pat 1. Fish Population Analysis. FAO Manuals in Fisheries Science, 4, Rome, 154p.

GIL, H. R. \& MARTINEZ, R. E. A., 1995, El bagre rayado Pseudoplatystoma fasciatum (Linnaeus) y Pseudoplatystoma tigrinum (Valenciennnes) aspectos biológicos y pesqueros en el alto río Meta. Boletín Científico INPA, 3: 157-167.

GODINHO, H. P., MIRANDA, M. O. T., GODINHO, O. L. \& SANTOS, J. E., 1993, Pesca e biologia do surubim Pseudoplatystoma corruscans no rio São Francisco, em Pirapora, MG. Reunião do grupo de avaliação técnica de Siluriformes do Brasil, Pirassununga. Bol. Tec. CEPTA.

LOUBENS, G. \& PANFILI, J., 2000, Biologie de Pseudoplatystoma fasciatum et Pseudoplatystoma tigrinum (Teleostei: Pimelodidae) dans lê bassin du Mamoré (Amazonie Bolivienne). Ichthyl. Explor. Freshwaters, 11: 13-34.

LOWE-MCCONNEL, R. H., 1975, Fish communities in tropical freshwaters. London, Longman, 284p.
MARQUES, E. E., 1993, Biologia reprodutiva, alimentação natural e dinâmica da nutrição do pintado, Pseudoplatystoma corruscans (Agassiz, 1829) (Osteichthyes, pimelodidae) no Alto Rio Paraná. Dissertação de Mestrado, PPG em Zoologia, UFPR, Curitiba, PR, 105p.

MATEUS, L. A. F. \& ESTUPIÑÁN, G. M. B., 2002, Fish stock assessment of piraputanga Brycon microlepis in the Cuiabá river basin. Braz. J. Biol., 62: 165-170.

PAULY, D., 1980, On the interrelationships between natural mortality, growth parameters and mean environmental temperature in 175 fish stocks. International Council for the Exploration of the Sea, 39: 175-192

REID, S., 1983, La biología de los bagres rayados Pseudoplatystoma fasciatum y $P$. tigrinum en la cuenca del río Apure, Venezuela. Revista Unellez de ciencia y Technologia, 1: 13-41.

REINA, M. P., RAMÍREZ, H. \& VALDERRAMA, M., 1995, Edad y crecimiento de Paulicea lüetkeni (Steindachner, 1876) (Pisces: Pimelodidae) basado en la lectura de estructuras duras (espinas de aleta pectoral) en el alto río Meta (Colombia). Boletin Científico INPA, 3: 115-130.

RESENDE, E. K., CATELLA, A. C., NASCIMENTO, F. L., PALMEIRA, S. S., CANDIDO, R. A., LIMA, M. S. \& ALMEIDA, V. L. L., 1996, Biologia do curimbatá (Prochilodus lineatus), pintado (Pseudoplatystoma corruscans) e cachara (Pseudoplatystoma fasciatum) na bacia hidrográfica do rio Miranda, Pantanal, Mato Grosso do Sul, Brasil. Corumbá, MS: EMBRAPA - CPAP. Boletim de Pesquisa, 2: 1-75.

RICKER, W. E., 1975, Computation and interpretation of biological statistics of fish population. Bull. Fish. Res. Bd. Can., 191, 382p.

ROSSI-WONGTSCHOWSKI, C. L., DEL BIANCO, A. \& BRAGA, F. M. S., 1982, Estudos sobre estrutura, ciclo de vida e comportamento de Sardinella brailiensis (Steindachner, 1879), na área entre $22^{\circ} \mathrm{S}$ e $28^{\circ} \mathrm{S}$, Brasil. 1.Morfologia de otólitos. Bolm Inst. Oceanogr., 31: 57-76.

RUFFINO, M. \& ISAAC, V. J., 1999, Dinâmica populacional do surubim-tigre, Pseudoplatystoma tigrinum (Valenciennes, 1840) no médio Amazonas (Siluriformes, Pimelodidade). Acta Amazônica, 29: 463-476.

SILVA, C. J., 1990, Influência da variação do nível da água sobre a estrutura e funcionamento de uma área alagável do Pantanal Matogrossense (Pantanal de Barão de Melgaço, Município de Santo Antônio de Leveger e Barão de Melgaço-MT). PhD Thesis, UFSCar, São Carlos, SP, 250p.

SSENTONGO, G. W. \& LARKIN, P. A., 1973, Some simple methods of estimating mortality rates of exploited fish populations. J. Fish. Res. Bd Can., 30: 695-698.

VAZ, M. M., 2001, Problemas no ajuste da curva de crescimento do pacu, Piaractus mesopotamicus (Holmberg, 1887) (Pisces: Characidae), e seu manejo no Pantanal Mato-grossense. $\mathrm{PhD}$ Thesis UNESP, Jaboticabal, SP, 98p

VAZZOLER, A. E., 1996, Biologia da reprodução de peixes teleósteos: teoria e prática. EDUEM/SBI, Maringá, PR, 169p. 